\title{
Naididae (Clitellata : Oligochaeta) and Aeolosomatidae ( Polychaeta : Aphanoneura) Species associated with aquatic plants in Tigris River/ Baghdad / Iraq
}

\author{
Haifa J.Jaweir*
}

Mahran M.Radhi*

\author{
Received 25,January,2012 \\ Accepted 13,May,2012
}

\section{Abstract:}

339 individuals, were sorted from 22 samples collected from three sites in Tigris River including , Al- Sarafiya district (S1), Al- Jaderiyah district (S2) and AlZa'afaraniya district (S3), in addition to one site in the irrigation canal of the AlJaderiyah campus of the University of Baghdad (S4), and in Al- Jeish canal(S5) east Baghdad. The sorting results revealed that the highest number of individuals of 102 was recorded at S4, whereas the lowest number of 24 individuals was recorded at S2. Regarding the sites, site S4 was the richest site with $30 \%$ of the total number represented 16 species, while each of S3 and S5 had 8 species only with $17.11 \%$ and $28.60 \%$ of the total individuals number respectively. The values of Jaccared Similarity Index, shows that the highest similarity index of $81 \%$ was recorded between S2 \& S4.Sorted Naididae worms comprised, 17 species of the subfamily Naidinae with $59 \%$ of the total number, 10 species of them are new record to Iraq, and 6 species are new records to Tigris River. Four species of the Subfamily Pristininae were identified, with a percentage of $25 \%$ of the total number, two of them are new record to Iraq, while the other two are new records to Tigris River, in addition to two species of Aeolostomatidae (Aphanoneura: Polychaeta), with $16 \%$ of the total number , both of them are new records to Iraq. Nine genera were recorded, from which Nais was the most abundant genus, followed by genus Pristina. These two genera were found in all study sites. Four species of Chaetogaster were observed including, $\boldsymbol{C}$. cristallinus; C. diastrophus; C.Limnaei and C. langi, The first two species are new record to Iraq, and they are the most abundant species within the Chaetogaster collections . Uncinais minor, Slavina appendiculata and Allonais inaequalis were three species new record to Iraq. The first species was found in S5 and, second species in S1, while the third one was found in S1\& S5 . Three species of Dero were identified, including, D.dorsalis, D. obtusa and D. digitata, the first two species are new record to Iraq, and the last one is new record to Tigris RiverTwo species of Stylaria were observed including, $\boldsymbol{S}$. lacustris and $\boldsymbol{S}$. fossularis. Latter species was new record to Tigris River.Regarding the genus Nais, five species were recorded, including Nais varaibilis; $N$. comminus; $N$. simplex; $N$. paradalis and $N$. elinguis; The first three species are new record to Iraq, while the last two species are new record to Tigris River.According to subfamily Pristininae, Four species of Pristina were identified, P.aequiseta, P.longiseta, P. Proboscidea, and P. foreli. The first two species were the most abundant species of Pristina. P. foreli is new record to Iraq, while the other three species were new recods to Tigris River.Finally, a number of 55 individuals of genus Aeolosoma were recorded in S5 only, with two species including A. quarternarium and Aeolosoma leidyi, The two species are new record to Iraq.According to above results, it is clear that there were $14 \& 8$ species new records for Iraq and Tigris River in this investigation respectively.

Key words: Naididae, Aeolosomatidae, Tigris River, Oligochaeta

*Department of Biology, College of Science for Women University of Baghdad , Baghdad / Iraq 


\section{Introduction:}

Naididae are small, transparent aquatic worms, of Subclass Oligochaeta; Class Clitellata, Phylum Annelida, usually less than $2 \mathrm{~cm}$ long; characterize by asexual reproduction by paratomy ( budding), forming a chain of individuals; mature individuals occur seldom [1] They are an ecologically diverse family of worms common in both running and standing waters. Many naidids are sediment dwellers, but other species are characteristically found among aquatic macrophytes [2] with mosses and liverworts [3] and with filamentous algae [4] Presence of Naididae species may be associated with the sponge Metania spinata [5]or with gastropoda [6] . Wetzel\& Taylor [7]recorded some Naididae spp. from caves in Illinois and Missouri, USA

'Naididae' traditionally, has been treated as a family, but phylogenetic analysis based on 18S rDNA sequences support the premise that all members of the former Clitellate family Naididae are phylogenetically nested within the former family Tubificidae $[8,9,10,11]$. Erèus \& Gustavsson [12] had proposed that these taxa together should be regarded as a single family to ovoid this paraphyly of Tubificidae, suggesting that all Niadides should be classified as members of Tubificidae, and for this reason, Ersèus et al. [13] submitted an application to the ICZN commission requesting to use its power to give precedence to Tubificidae ,Vejdovesky 1876 over Naididae , Ehrenberg 1828, but the members of ICZN voted against it, Since the family-group name Naididae is older than Tubificidae, and thus, according to the International Code of Zoological Nomenclature, should have precedence over the latter. [14]

Naidinae comprised 21 known genera widespread in the world [15] They are easily identified by their external morphological characters such as chaetae , proboscis, and gills. The chaetae are considered as a very important feature for the identification of genera and species of Naidinae, including the segment on which dorsal chaetae commence; the number of chaetae per bundle; relative sizes of teeth of bifid chaetae, and presence or absence of hair chaetae. Niadinae are characterize by the presence of needle chaetae accompanied with hair chaetae in the dorsal bundles [ 15, 16, 17]. Pristina spp. were excluded from family Naididae by [16] and arranged them in a separate family named as family Pristinidae, which are very small worms have a dorsal setae beginning in segment II as in Tubificinae, breeding mostly by budding ( paratomy) like Niadinae ; Sexually mature individual, which occur seldom, reveal forward position of reproductive system, with male pores and clitellum mostly in VIII, and spermathecae in VII; Living on bottom surface and water plants, but never swimming [16] According to [15] Genus Pristina consist of 23 species ( with and without Proboscis) with $P$. longiseta, Ehrenberg, 1828 as a type species. Pristina species, without a proboscis, were placed in the genus Pristinella by [18] to separate them from other Pristina species with a proboscis. This separation was later suppressed by [19] . [16] considered Pristine, which have prostomium with proboscis, and Pristinella, which have simple prostomium, without proboscis, as subgenera

An aberrant family, Aeolosomatidae, may be treated as a separate class, Aphanononeura , which are representative of Calss Polychaeta [20] Aeolosoma with broad, ventrally ciliated prostomium bearing lateral sensory pits. They have coloured 
cutaneous glands, irregularly distributed, hair chaetae of different size found in both dorsal and ventral bundles [16] .

The aim of this study is to sort and identify microdrile worms associated with emergent plants and filamentous algae collected from Tigris River in Baghdad, and Al-jeish canal, east of Baghdad. Few investigators, have studied Oligochaeta species in Iraq [21,22,23] Most of these studies referred to Naididae, as a family group within the macrobenthic community samples [24,25,26,27,28]

\section{Materials and Methods:}

22 samples of aquatic plants, Ceratophyllum, and filamentous algae were collected from five sites on different aquatic habitats within Baghdad city, using a long hand digger to eradicate the plants. The sites include:

$\mathrm{S} 1$ - On the Tigris river at AlSarafyia district

S2- On the Tigris river at AlJaderyia district (at the bank of AlA'aras island)

S3- On the Tigris river at AlZa'afaranyia district

S4- from the irrigation canal inside Al- Jaderyia campus of the University of Baghdad. This irrigation canal derives its water from Tigris river in Al- Jaderia.

S5- On Al- Jeish canal east Baghdad. This irrigation canal connect Tigris river, North Baghdad to River Diyala, before its connection with River Tigris, South of Baghdad After S3The eradicated plants and algae were collected in large containers containing water from the site, and transferred to the laboratory, where they were distributed into three glass aquarium of $(40 \times 20 \times 20 \mathrm{~cm}$.), and left for about 7-10 days to allow the worms to settle down. Air pump was used to aerated water in each aquarium. the settled sediment on the bottom of aquarium was collected with care by fine dropper, and transferred to a Petri dishes of $10 \mathrm{~cm}$ diameter. The worms then sorted carefully using dissecting microscope, and transferred to a clean Petri dish containing little amount of tap water . $10 \%$ formalin was then added drop by drop to the dish to kill the worms. The sorted worms then preserved in $70 \%$ alcohol. Wet-funnel was also used for sorting the remaining small worms in the aquarium, as described by [16] Permanent slides were prepared as $[15,16]$ Worms of family Aeolosomatidae should be identified alive since tending to burst and lose most taxonomically important structures at fixation[16] worms were identified according to [15,16,17,29]

The similarity between the sites was calculated by Jaccard Index ( ISj) according to the [30]

\section{Results and Discussion :}

339 individuals of 23 species were sorted belonging to the family Naidinae ( 17 species ); Pristininae

( 4 species) and Aeolosomatidae ( 2 species) in different study site ( Table 1). Table (1) also shows all data concerning the identified species, the number of individuals of each species in each study site and their percentage occurrence frequencies . It was clear that Nias variabilis was the most abundant species, which shows $100 \%$ occurrence frequency, the other species of Nais were $N$. elinguis; $N$ simplex , $N$ paradilus, and $N$. communis, with frequencies of 4.5; 36; 18; and $27 \%$ respectively. Four species of each of Chaetogaster,( cristallinus; $\quad C . \quad$ diastrophus; C.Limnaei and C. langi) and Pristina, (P. longiseta; $P$ aequiseta; $P$. proboscidea and $\boldsymbol{P}$ foreli ) and three species of Dero. D.dorsalis, D. digitata and D. obtuse. Each of Slavina, 
Allonais and Uncinais were represented by only one species with low occurance frequencies. The highest number of individuals collected from S4 \& S5 of $102 \& 97$ individuals respectively, and comprised $30.1 \& 28.6 \%$ of total number ( Fig 1). Higher diversity was recorded in S4, in which the community comprised 16 species, 14 , 13 species were recorded in S1 and S2 respectively, while each of S3 and S5 have 8 species only ( Fig 1).Sorting Naididae worms comprised 17 species of the subfamily Naidinae, and 4 species of subfamily Pristininae, in addition to 2 species of Aeolostomatidae. They were recorded a percentage of 59,25 and $16 \%$ respectively ( Fig 2).Fig (3) shows that nine genera were recorded, in which Nais was the most abundant genus, followed by genus Pristina which had four species These two genera found in all study site in addition to Dero, which found in all sites except S5. The genus Allonais was found in S1 \& S5. While Slavina and uncinais were found in one site only, S3 \& S5 respectively. 55 individuals of Aeolosoma were recorded in S5 only.Fig ( 4) shows the numbers of normal , paratomic and sexual individuals for all sorted worms during the study months. The lowest total worms was sorted in September, then it increased progressively in October and November, decreased again during the cold months of December, January and February . Starting from March the number increased progressively to reach its peak in June.. It was clear from this figure that the paratomic individuals started their appearance during March and then increase in number progressively during April, May and June, while the sexual individuals were very rare, and few individual of them appeared in the sample of June which belong to $N$. variabilis. This result is confirmed by [6,31] who indicated that the mature individuals occur seldom, Members of subfamily Niadinae, reproduce both asexually and sexually. In populations that reproduce sexually, there is apparently one sexual generation a year, usually occurring during the summer and autumn. Adults die soon after laying their cocoons [1]Asexual reproduction is employed by species of Naididae during favorable environmental conditions. Cocoon deposition allows a population to survive period of environmental stress [32] This fact discussed our result which shows a decline in numbers of individuals during winter season, during December, January and February.In Iraq very little data are available about this group of invertebrate to compare with our results, but our result is closely related with Turkish fauna recorded by [33,34] . In Iraq Stylaris species was recorded by many authers [26,27,28], due to their large size and activity and they can swim, so they may be easily detected with benthic fauna, while species like Slavina is always incrusted with foreign matter and is difficult to detect by naked eyes. Other genera were, also recorded separately by some authors, such as [26,27] Pristina [22,23] and Chaetogaster [21][35]referred to the presence of Aeolosoma sp. in Al-Diwanyia river. Acoording tothe above results , 14 species were considered as new records for Iraq, they are never recorded in any Iraqi litreture. and eight speies as new record to Tigris River, which were previously recorded in different sites other than Tigris River.According to the study sites , Jaccard similarity test indicated that the similarities in the community of Tigris river Stations ( S1,S2, S3) were ranged between $40-60 \%$, while there was a higher similarity between S2 
(Tigris river in Al-Jaderyia) and S4 ( irrigation canal of Al-jaderyia campus of the Univ. of Baghdad, which reach to $81 \%$. S5 was the most different site which recorded a range of similarity index between $14.3-23.5 \%$ with other sites. (Table, 2).

Table( 1): Numbers of Naidinae, Pristininae, and Aeolosotomatidae species Identified in different sites of freshwater habitat in Baghdad City

\begin{tabular}{|c|c|c|c|c|c|c|c|c|}
\hline \multirow[t]{2}{*}{ family } & \multirow[t]{2}{*}{ species } & \multirow{2}{*}{$\begin{array}{l}\text { Study } \\
\text { Sites } \\
\text { S1 }\end{array}$} & \multirow{2}{*}{$\begin{array}{l}\text { Total } \\
\text { (ind.) }\end{array}$} & \multirow{2}{*}{$\begin{array}{l}\text { Frequency } \\
\% \\
\text { S3 }\end{array}$} & \\
\hline & & & & & S4 & S5 & & \\
\hline \multirow{17}{*}{ Naidinae } & $\begin{array}{l}\text { Chaetogaster* } \\
\text { cristallinus }\end{array}$ & 2 & 1 & 0 & 3 & 0 & 6 & 27 \\
\hline & C. limnae ${ }^{* *}$ & 0 & 0 & 0 & 1 & 0 & 1 & 4.5 \\
\hline & C.langi** & 0 & 0 & 0 & 0 & 1 & 1 & 4.5 \\
\hline & C. diastrophus* & 2 & 1 & 0 & 4 & 0 & 7 & 31.8 \\
\hline & $\begin{array}{l}\text { Uncinais } \\
\text { minor* }\end{array}$ & 0 & 0 & 0 & 0 & 2 & 2 & 4.5 \\
\hline & Dero dorsalis* & 1 & 1 & 0 & 2 & 0 & 4 & 18 \\
\hline & D. digitata** & 5 & 2 & 5 & 5 & 0 & 17 & 50 \\
\hline & D. obtusa* & 0 & 2 & 5 & 4 & 0 & 11 & 36 \\
\hline & $\begin{array}{l}\text { Stylaria } \\
\text { lacusrtis }\end{array}$ & 10 & 2 & 9 & 9 & 0 & 30 & 54 \\
\hline & S. fossularis** & 6 & 1 & 8 & 7 & 0 & 22 & 59 \\
\hline & $\begin{array}{l}\text { Slavina } \\
\text { appendiculata* }\end{array}$ & 2 & 0 & 0 & 0 & 0 & 2 & 4.5 \\
\hline & $\begin{array}{l}\text { Allonaias } \\
\text { inaequalis* }\end{array}$ & 1 & 0 & 0 & 0 & 1 & 2 & 9 \\
\hline & Nais variabilis* & 11 & 5 & 13 & 21 & 14 & 64 & 100 \\
\hline & N.elinguis** & 0 & 0 & 0 & 1 & 0 & 1 & 4.5 \\
\hline & N. simplex* & 4 & 2 & 0 & 8 & 0 & 14 & 36 \\
\hline & N. paradalis $* *$ & 0 & 2 & 0 & 5 & 0 & 7 & 18 \\
\hline & N. communis* & 0 & 0 & 4 & 4 & 0 & 8 & 27 \\
\hline \multirow[t]{4}{*}{ Pristininae } & $\begin{array}{l}\text { Pristina } \\
\text { longiseta** }\end{array}$ & 9 & 2 & 8 & 12 & 13 & 44 & 81 \\
\hline & P. aequiseta* & 4 & 2 & 6 & 8 & 11 & 31 & 68 \\
\hline & P. foreli* & 0 & 1 & 0 & 8 & 0 & 9 & 27 \\
\hline & $\begin{array}{l}P . \\
\text { proboscidea** }\end{array}$ & 1 & 0 & 0 & 0 & 0 & 1 & 4.5 \\
\hline \multirow[t]{2}{*}{ Aeolosomatidae } & $\begin{array}{l}\text { Aeolosoma } \\
\text { aquaternarium* }\end{array}$ & 0 & 0 & 0 & 0 & 20 & 20 & 18 \\
\hline & A. leidyi* & 0 & 0 & 0 & 0 & 35 & 35 & 18 \\
\hline Total & & 58 & 24 & 58 & 102 & 97 & \multirow{2}{*}{339} & \\
\hline No. of species & & 14 & 13 & 8 & 16 & 8 & & \\
\hline
\end{tabular}

* New record for Iraq.

Table(2): Values of Jaccard simmilaty index

\begin{tabular}{|c|c|c|c|c|}
\hline & S1 & S2 & S3 & S4 \\
\hline S2 & 0.625 & & & \\
\hline S3 & 0.400 & 0.500 & & \\
\hline S4 & 0.526 & 0.813 & 0.500 & \\
\hline S5 & 0.235 & 0.167 & 0.231 & 0.143 \\
\hline
\end{tabular}




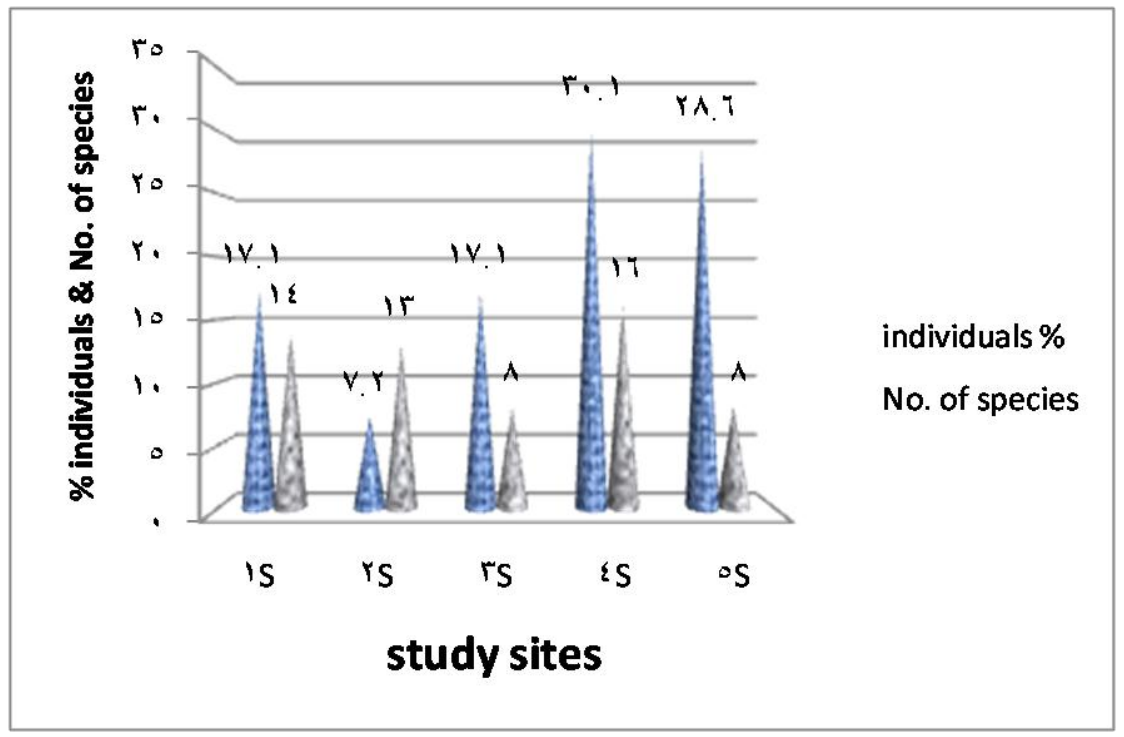

Fig(1): percentage of total worms and number of species collected from different study sites

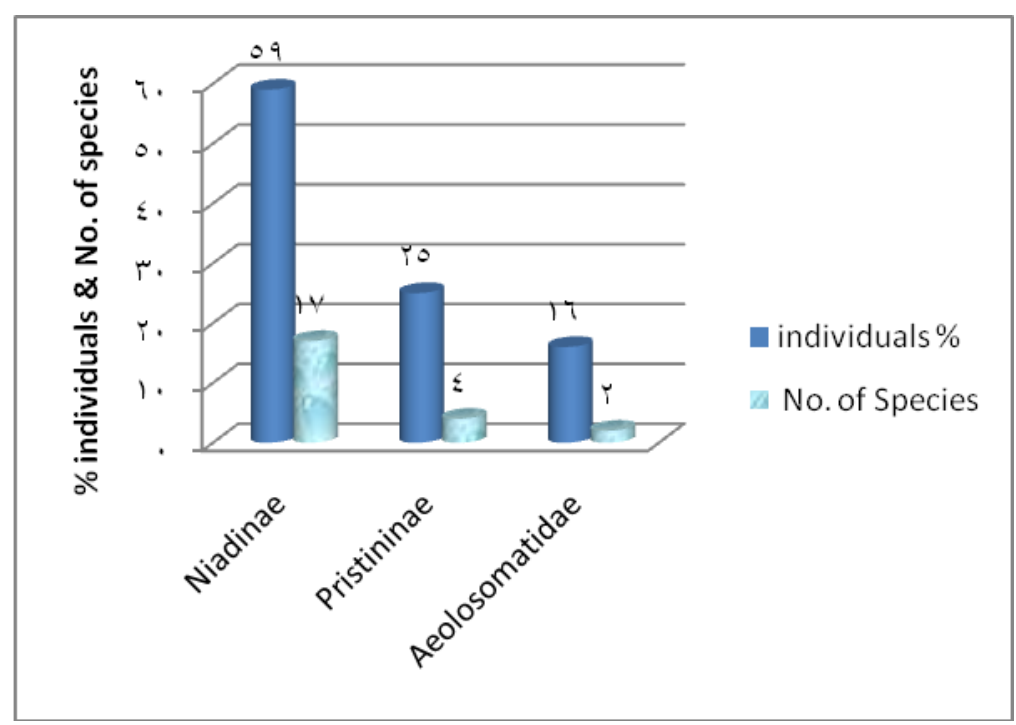

Fig (2): Percentages of identified number of individuals of each Aquatic worms families. 


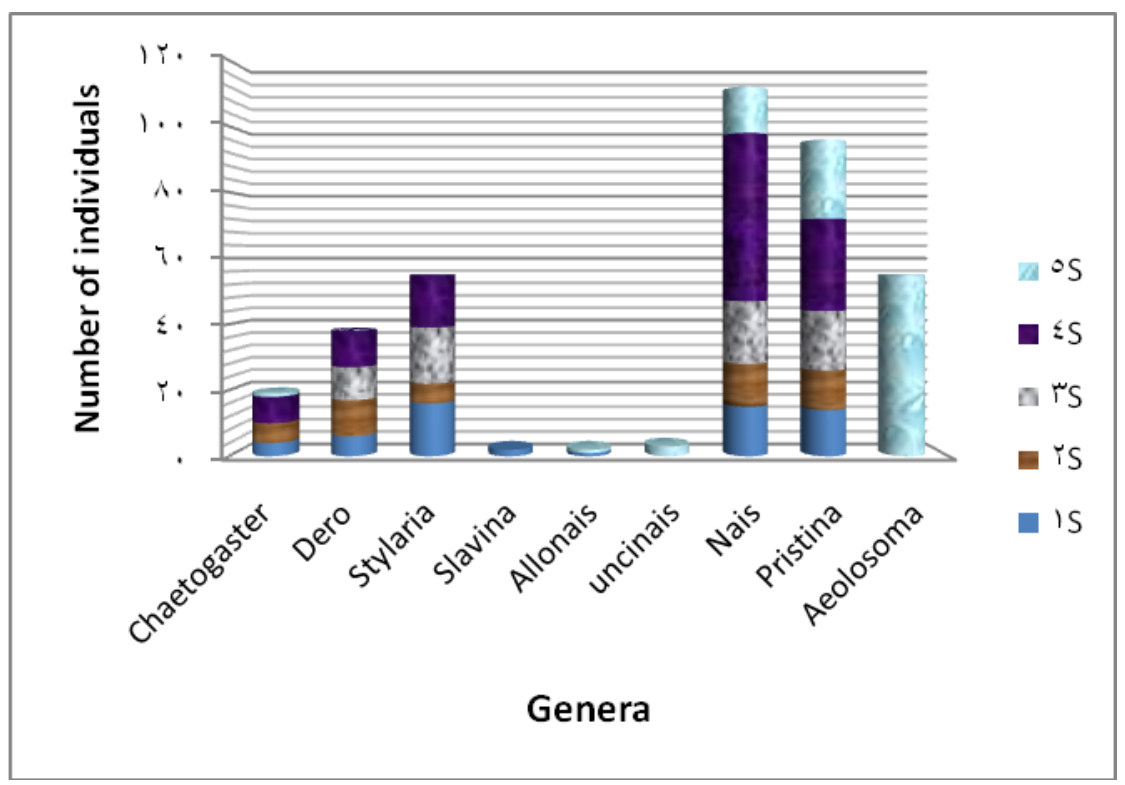

Fig (3): Number of identified individuals of different genera collected from different study sites.

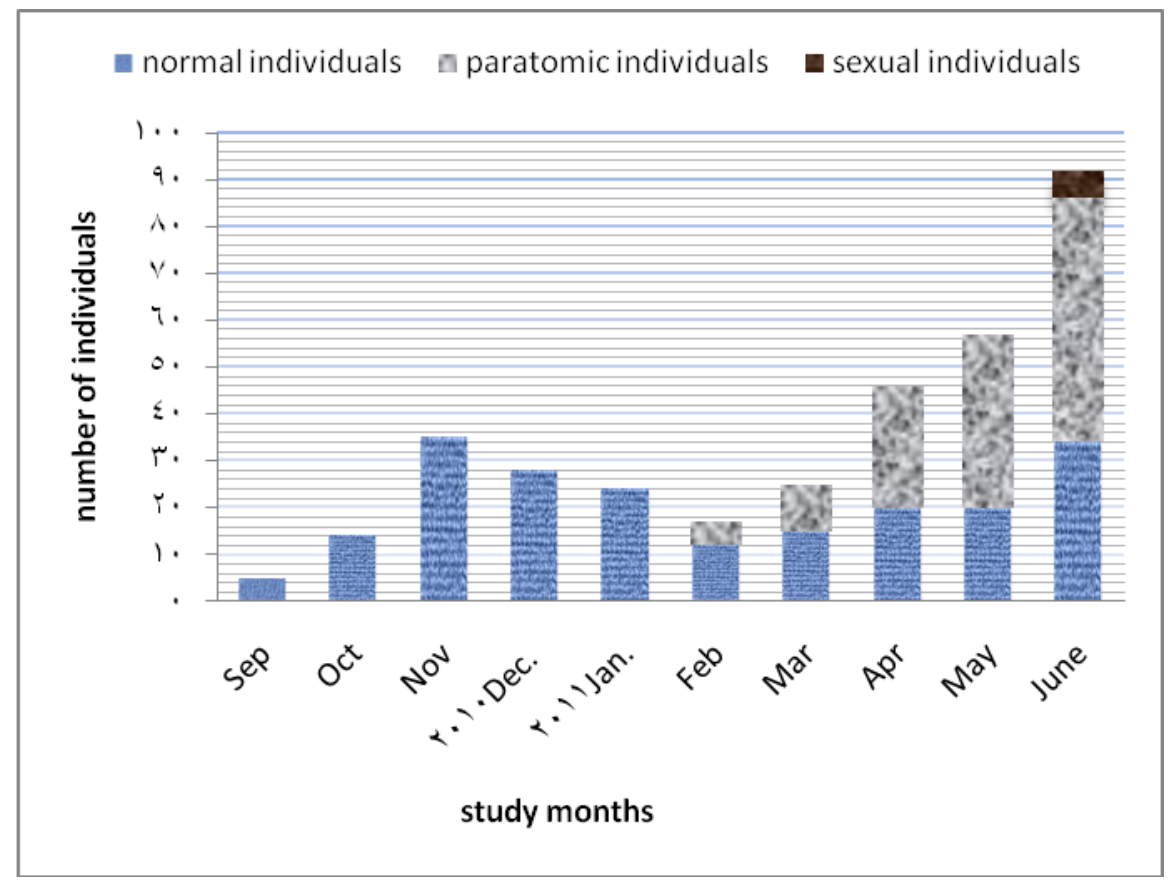

Fig (4) : Number of normal, paratomic and sexual individuals for all sorted worms during the study months.

\section{References:}

1- Learner, M.A., Lochhead, G. and Hughes, B.D 1978 A review of the biology of British Naididae (Oligochaeta) with emphasis on the lotic environment. Freshwater Biol., 8(4):357-375.
2- Alves , R. da G and Gorni , G.R. 2007 Naididae species ( Oligochaeta) associated with submersed aquatic macrophytes in two reservoir (Säo Paulo , Brazil). Acta. Limnol. Bras., 19(4): 407-413. 
3- Gorni, G.R. and Alves, R. da G. 2007 Naididae ( Annelida, Oligochaeta) associated with briophytes in Bärotas, State of Säo Paulo, Brazil. Revista Brasileira de Zoologia 24 (2): 518-519.

4- Armendariz, L.C. 2000 Population dynamics of Stylaria lacustris ( Linnaeus,1767) ( Oligochaeta, Naididae) in Los Talas, Argentina. Hydrobiologia, 438: 217:226.

5- Gorni, G.R. and Alves, R. da G. 2008 Naididae ( Annelida, Oligochaeta) associated with the sponge Metania spinata ( Carter, 1881) ( porifera: Metaniidae) from a southeastern Brazilian reservoir. Acta Limnol.Bras.20 (3): 261-263.

6- Gorni, G.R., and Alves, R. da G. 2006 Naididae (Annelida, Oligochaeta) associated with Pomacea bridgesii (Reeve) (Gastropoda, Ampullaridae). Revista Brasileira de Zoologia, 23(4): 1059-1061.

7- Wetzel,M.J. and Taylor, S.J. 2001. First records of freshwater oligochaetes ( Annelida, Clitellata) from caves in Illinois and Missouri, USA. Journal of Cave and Karst Studies, 63(3): 99-104.

8- Erséus, C., Prestegaard, T., and Källersjö, M. 2000 Phylogenetic analysis of the Tubificidae (Annelida, Clitellata) based on 18S rDNA sequences. Molecular Phylogenetics and Evolution, 15: 381-389.

9- Erséus, C., Källersjö, M., Ekman, M. and Hovmöller, R .2002 18S rDNA phylogeny of the Tubificidae (Clitellata) and its constituent taxa: dismissal of the Naididae. Molecular Phylogenetics and Evolution, 22: 414-422.

10- Erséus, C 2005 Phylogeny of oligochaetous Clitellata. Hydrobiologia, 535/536: 357-372.

11- Envall, I. 2009. Evolutionary Perspective on Naidinae (Annelida, Clitellata, Naididae):Molecular and Morphological Revelations. Ph.D. thesis, Stockolms Univ.,48 pp

12- Erséus, C. and Gustarsson, L. 2002 A proposal to regard the former family Naididae as a subfamily within Tubificidae (Annelida, Clitellata). Hydrobiologia, 485:253-256.

13- Erséus, C., Gustavsson, L. and Brinkhurst, R.O .2005 Case 3305. Tubificidae Vejdovský, 1876 (Annelida, Clitellata): proposed precedence over Naididae Ehrenberg, 1828. Bulletin of Zoological Nomenclature, 62, 226-231.

14- Erséus, C., Wetzel, M.J. and Gustavsson, L. 2008 ICZN rules-a farewell to Tubificidae (Annelida, Clitellata). Zootaxa, 1744: 66-68.

15- Brinkhurst, R.O. and Jamieson, B.G 1971 The Aquatic oligochaeta of the world.

Edinburgh, Oliver \& Boyd. XI, 860pp.

16- Timm, T. 2009 A guide to freshwater oligochaeta and polychaeta of northern and central Europe. Lauterbornia, 66: 1-23.

17- Pinder, A. 2010 Tools for identifying selected Australian aquatic oligochaetes (Clitellata : Annelida). Museum Victoria Science Reports 13: $1-26$.

18- Brinkhurst, R.O. 1985 The generic and subfamilial classification of Naididae (Annelida: Oligochaeta). Proceedings of the Biological Society of Washington 98(2): 470-475.

19- Collado, R., and R.M. Schmelz 2000 Pristina silvicola and Pristina terrena spp.nov., two new soil-dwelling species of Naididae (Oligochaeta, Annelida) from the tropical rain forest near Manaus, Brazil, with comments on the genus Pristinella. J. Zool. London 252: 509-516.

20- Timm, T 1981 On the origin and evolution of aquatic oligochaeta. EstiNSV Teuduste Akademia Toimetised Biologia, 30: 174-181.

21- Al-Abbad, M.Y. 2009 Identification and Biology of the species chaetogaster limnaei ( Oligochaeta: Naididae) isolated from some Basrah marshes snail in the south 
ofof Iraq. PhD. Thesis . College of Education, Univ. of Basrah. Iraq 145pp.

22- Al-Abbad ,M.Y.M. 2010 New records of pristine proposcidea and $\mathrm{P}$. aquiseta (oligochaetes : Naididae) from Iraq,Marsh Bulletin, 5(2): 132142.

23- Al-Abbad ,M.Y.M. and Al-Mayah, S.H. 2010 New records of two species of oligochaetes ( Naididae): pristine longiseta and P. Macrochaeta from Iraq, with note on their morphology and reproduction. Mesopot. J. Mar.Sci. 25(2) : 57-66.

24- Al-Lami, A. A.; Jaweir, H. J., and Nashaat, M.R. 1998 Benthic Invertebrates community of river Euphrates upstream and downstream sectors of Al-Qadisia dam, Iraq. Regul. Rivers- Res. Manage. 14(4): 383-390.

25- Nashaat, M.R., AL-Lami, A.A. and Jaweir, H.J 2000 Benthic fauna of Qadisia Lake, north-west Iraq. J. Diala, 8(1): 74-83.

26- Ali, L.A. 2007 A study of macroinvertebrates communities in the middle sector of greater Zab River / Iraq . PhD. Thesis, College of Science for Women, University of Baghdad.123pp.

27- Sabtie, H.A . 2009 An ecological study of the benthic macroinvertebrates community in the Southern Marshes of Iraq. Ph.D.thesis, Colloge of Science for Women, Baghdad Univ., 167pp.

28- Nashaat, M.R. 2010 Impact of AL-Durah Power Plant effluents on physical, chemical and invertebrates biodiversity in Tigris River Southern Baghdad. Ph. D. thesis, College of Science, Baghdad Univ. 183pp.

29- Brinkhurst, R.O1971 . A guide for the Identification of British aquatic Oligochaeta. ( $2^{\text {nd }}$. Ed.). Scientific publication No. 22. Freshwater Biological Association, UK.

30- Southwood, T. R. E. 1978Ecological Methods with Particular Reference to the Study of Insect Populations. Second Edition. London Chapman and Hall: 524pp.

31- Ladle, R.J. and Todd, P.A. 2006 Sex or sanctuary: how do asexual worms survive the winter? Hydrobiologia, 559: 395-399.

32- Parish, J1981 Reproductive ecology of Naididae (Oligochaeta). Hydrobiologia, 83: 115-123.

33- Arsaln P. and Şahin Y2003

Nine New Naididae (Oligochaeta) species for Sakarya River, Turky. J. Zool., 27: 27-38.

34- Arslan, N., and Ilhan, S. 2010 Distribution and abundance of Oligocgaeta (Annelida) species and environmental variables of Porsuk Stream (Sakarya River, Turkey). Review of Hydrobiology, 3,1: 51-63. 35- Al-Kuti, S.S.I. 2000 Use of Annelida-Oligochaeta, as bioindicators in pollution in ALDiwania River. M.Sc. thesis, College of Education, AL- Qadisiyah Univ., 80pp. In Arabic 


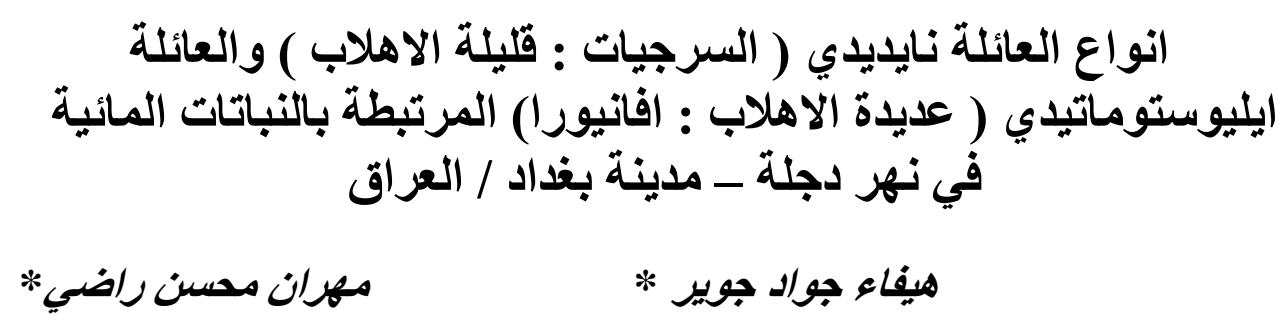

* كلية العلوم للبنات / جامعة بغداد

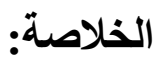

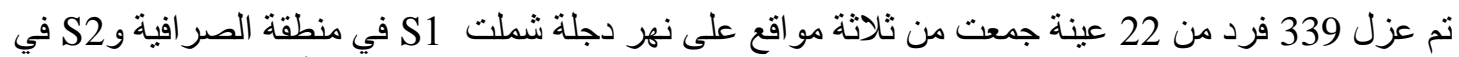

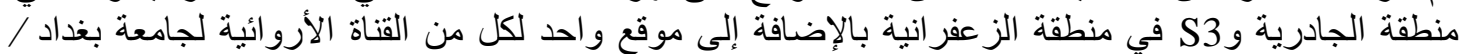

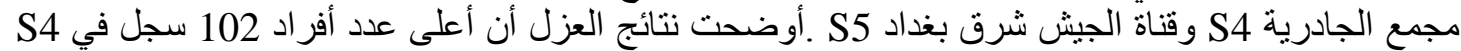

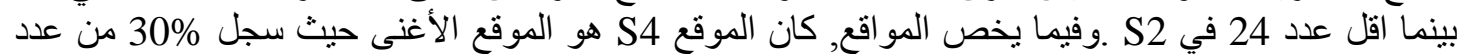

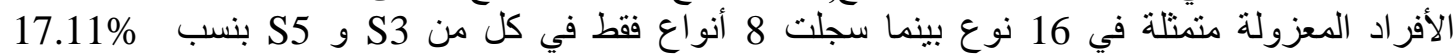

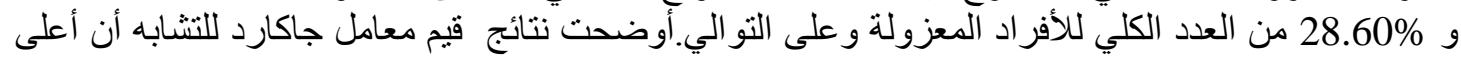

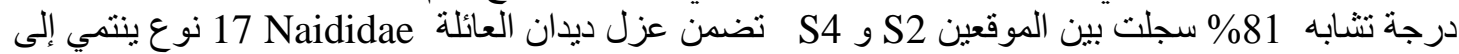

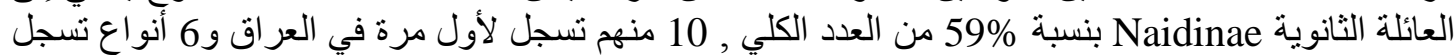

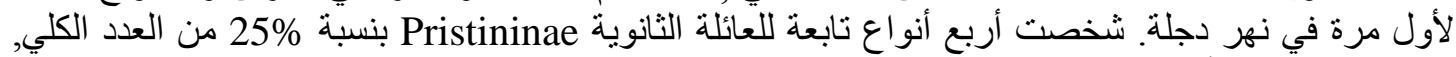

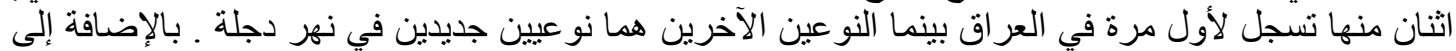

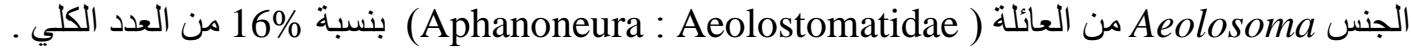

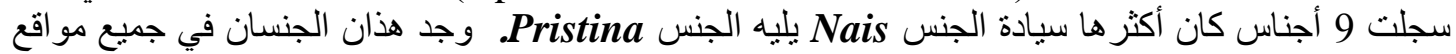

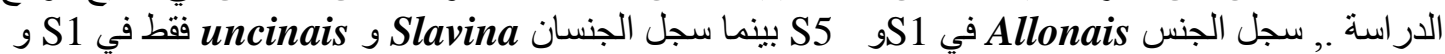

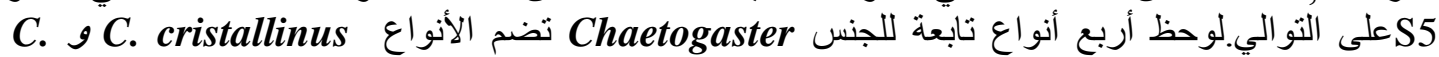
يعتبر النوعان الأولان تسجيل جديد في العراق وهما أكثر C C langi و C.Limnaei sdiastrophus

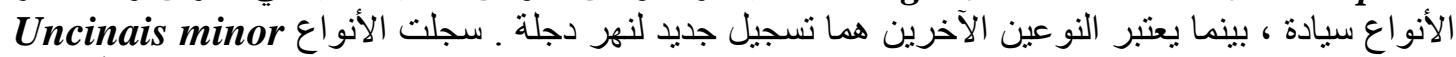

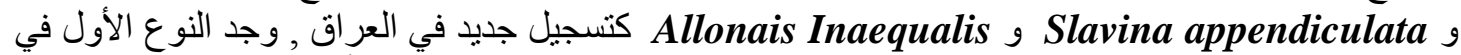

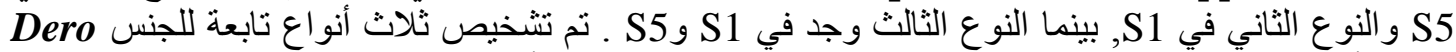

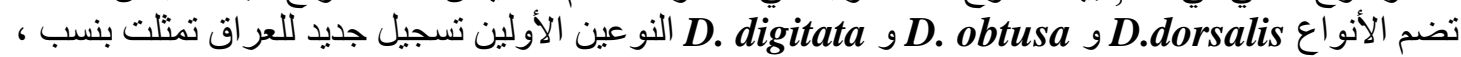

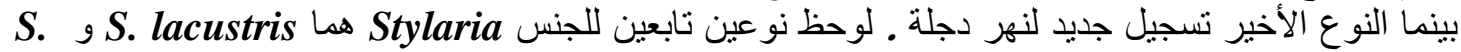

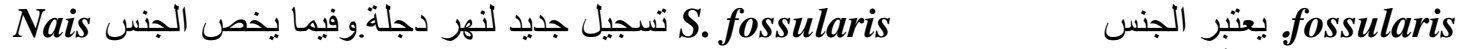

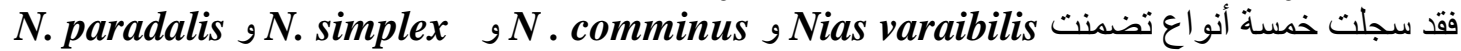
و ت تعثبر الأنواع الثلاث الأولى تسجيل جديد للعراق, بينما النو عين الآخرين تسجيل جديد لنهر

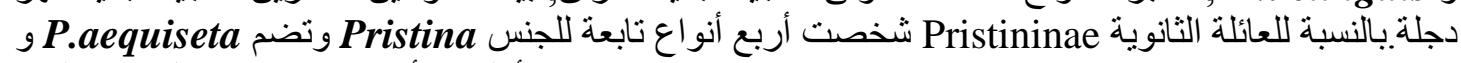
يعتبر النوعين الأولين الأكثر تواجد وتسجيل جديد لنهر

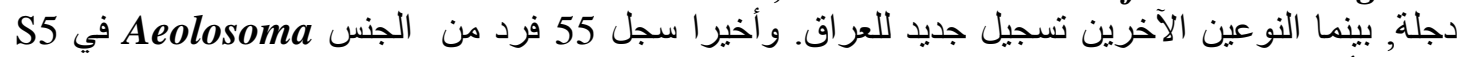

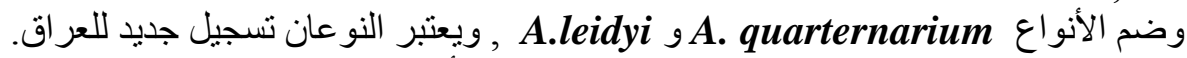
توضح النتائج اعلاه تسجيل 14 نوع جديد للعر اق و 8 أنواع جديدة لنهر دجلة. 